\title{
Computational modelling of TNFa related pathways regulated by neuroinflammation, oxidative stress and insulin resistance in neurodegeneration
}

\author{
Hemalatha Sasidharakurup and Shyam Diwakar ${ }^{*}$ (D)
}

\author{
* Correspondence: shyam@amrita. \\ edu \\ Amrita School of Biotechnology, \\ Amrita Vishwa Vidyapeetham, \\ Amritapuri Campus, Kollam, Kerala, \\ India
}

\begin{abstract}
Computational and mathematical modelling towards understanding the structure and dynamics of biological systems has significantly impacted on translational neuroscience to face novel approaches toward neurological disorders such as Alzheimer's (AD) and Parkinson's disease (PD). In this study, a computational model of $A D$ and $P D$ have been modelled using biochemical systems theory, and shows how Tumour Necrosis Factor alpha (TNF훼) regulated neuroinflammation, oxidative stress and insulin pathways can dysregulate its downstream signalling cascade that lead to neurodegeneration observed in AD and PD. The experimental data for initial conditions for this model and validation of the model was based on data reported in literature. In simulations, elevations in the aggregations of major proteins involved in the pathology of $\mathrm{AD}$ and $\mathrm{PD}$ including amyloid beta, alpha synuclein, tau have been modelled. Abnormal aggregation of these proteins and hyperphosphorylation of tau were observed in the model. This aggregation may lead to developing Lewy bodies, fibrils, plaques and tangles inside neurons that trigger apoptosis. An increase in the concentrations of TNF 훼 and glutamate during diseased conditions was noted in the model. Accumulation of these proteins may be related to the feedback mechanism of $\mathrm{TNF}$ 훼 that initiates its own release and the production of excess glutamate. This could lead to the prolonged activation of microglia that result in death of surrounding neurons. With the elevation in reactive oxygen species, oxidative stress also increased. Simulations suggest insulin may be an important factor identifying neurodegeneration in $\mathrm{AD}$ and $\mathrm{PD}$, through its action along with the neuroinflammation and oxidative stress. Low insulin level was noticed in the diseased condition due to abnormal protein aggregation that leads to TNF $\alpha$ release. Given the role towards better design of real experiments, accumulation of oligomers of mutated proteins in $\mathrm{AD}$ and PD activating microglia and secreting TNF $\alpha$ along with other cytokines map to oxidative stress that led to cell death.
\end{abstract}

Keywords: Tumor necrosis factor alpha, Insulin, Parkinson's disease, Alzheimer's disease, Systems theory, Mathematical modelling, Inflammation, Oxidative stress 


\section{Introduction}

Alzheimer's disease $(\mathrm{AD})$ is a major neurodegenerative disorder often related to the deposition of amyloid $\beta$-peptide $(A \beta)$ plaques in brain tissue followed by formation of neurofibrillary tangles (Murphy and Levine 2010) and is associated to symptoms such as memory loss, alterations in mood and behavior and have been associated with, dementia, disorientation and aphasia (Jahn 2013). Parkinson's disease (PD) is the second most prevalent neurodegenerative disorder that causes death of dopaminergic neurons in substantia nigra pars compacta of the midbrain, which leads to the decline in the synthesis of dopamine (Mhyre et al. 2012). It is also characterised by a large number of motor and non-motor features and by the increase in incidence above the age of 65 (Mahlknecht et al. 2015). The clinical manifestations of PD include resting tremor, muscular rigidity, bradykinesia, depression and postural instability (DeMaagd and Philip 2015). According to the Alzheimer's Association, National Institutes of Health in the United States of America spends $\$ 480$ million on Alzheimer's research compared to $\$ 3$ billion on HIV/AIDS, \$4 billion on heart disease and \$6 billion on cancer. PD affects 1-2 per 1000 of the population with its prevalence increasing with age and affecting about 1\% of the population above 60 years (Tysnes and Storstein 2017). Therefore, discovery and characterization of accurate biomarkers play a crucial role in disease prediction (Padmanabhan et al. 2017). Both, genetic and environmental factors, have been identified related to the risks of developing AD (Killin et al. 2016). If the condition can be detected earlier, effective treatment can help manage the condition although, often, fewer symptoms manifest in the early stages resulting in late detection of the disease. The biomarkers till date change with the factors and illness, and it may not be expressed all the time. One of the main medications given for PD patients is L-Dopa (Hardebo and Owman 1980). Although, several experimental models to analyse the disease pathology have been developed, there are aspects regarding the pathological cascade of both sporadic and familial conditions (Golde et al. 2013; Ferreira et al. 2015) that need to be addressed. A reason behind this is the limitations in conducting in vitro and in vivo experiments with neurons (Polikov et al. 2007) and the complexity in neuronal circuits. For example, in the case of $\mathrm{AD}$, it is difficult to extract $\beta$ amyloid aggregates from neural specimens, and previous reports indicate aggregates in saline cause toxicity in vitro (Esparza et al. 2016; Giorgetti et al. 2018). Although there is evidence that amyloid $\beta$ oligomers contribute chronic neurological manifestations, they are difficult to be detected by conventional staining techniques (Ferreira et al. 2015).

There are some drugs available to manage the symptoms, despite decades of research, no treatment has been reported to completely halt the disease conditions yet (Padmanabhan et al. 2017). Since the disease mechanisms are poorly understood, especially in case of major proteins such as alpha synuclein $(\alpha S)$, amyloid $\beta$ and tau that form fibrils, plaques and tangles, it is difficult to turn them off and patients are diagnosed late or remain undiagnosed (Bendor et al. 2013; Razzokov et al. 2019). Studies have also suggested the accumulation of $A \beta$ and $\alpha S$ in the brain during the natural process of aging (Li et al. 2004). As these aggregated proteins lead to signal cross-talk within the brain, it may be associated to further signalling cascades which initiates onset of the disease. This includes several abnormal cell damage events such as mitochondrial dysfunction, oxidative stress, hyperphosphorylation of tau, increased neuro-inflammatory responses, decreased neuroplasticity and neurogenesis, neurodegeneration etc. (de JR de Paula 
et al. 2009). Recent studies have shown that during neuroinflammation, the release of TNF $\alpha$ by activated astrocytes and microglia was linked to AD and PD (Reddy and Seth n.d. ; Olmos and Lladó 2014).

Inflammation in the brain may be promoted by invasion of pathogens, spinal cord injury, aggregation of misfolded proteins, tangles, plaques. The cellular insults activate microglia and initiate the production of proinflammatory cytokines to protect neurons from tissue damage initially, which results in neurodegeneration (Amor et al. 2010). Tumour necrosis factor alpha (TNF훼), a major proinflammatory cytokine, has been known to have an important role in neuroinflammation and glutamate mediated excitotoxicity related to AD and PD (A Frankola et al. 2011; Olmos and Lladó 2014). It has been reported that $\mathrm{TNF} \alpha$ along with surface receptors, are present in healthy brain at low levels, and high levels in diseased states (Santello and Volterra 2012). Under normal physiological conditions, the production of excess TNF $\alpha$ is controlled by inhibiting activation of microglia (Wang et al. 2015). During inflammation, astrocytes and microglia become activated through initiation of proinflammatory triggers and cytokines release due to $\mathrm{T}$ cells infiltration (Liberman et al. 2019). $A \beta$ and $\alpha \mathrm{S}$ have been reported as key proteins that trigger neuroinflammation in $\mathrm{AD}$ and PD respectively (Tweedie et al. 2012). Amyloid plaques have been known to cause neurodegeneration due to the toxic effect of $A \beta$ (Pasinetti and Hiller-Sturmhöfel 2008). Hyperphosphorylation of tau forms neurofibrillary tangles that again leads to intracellular lesions in the brain (de JR de Paula et al. 2009). In vitro and in vivo studies have shown that mutations in genes code of amyloid precursor protein, presenilin 1 and 2 trigger plaque formation (Żekanowski et al. 2003). In earlier studies, the involvement and presence of TNF $\alpha$ around $\mathrm{A} \beta$ plaques have been reported in the post-mortem brain tissue of both transgenic $\mathrm{AD}$ mice and AD conditions (Chang et al. 2017). A study had reported the role of neuroinflammation and TNF $\alpha$ signalling in the early stages of $\mathrm{AD}$ and its role in neurodegeneration through accumulation of plaques, neurofibrillary tangles and elevations of misfolded or mutated proteins/genes involved (Montgomery and Bowers 2012). Experiments on both animal and human PD brain tissues suggested that abnormal levels of TNF $\alpha$ released by high microglial activation can lead to dopaminergic cell death (Yiannopoulou and Papageorgiou 2013). Elevation in accumulation of $\alpha \mathrm{S}$ aggregates activates microglia in turn increasing the production and release of excess TNF $\alpha$ (Zhang et al. 2018). Both $A \beta$ plaques and $\alpha \mathrm{S}$ aggregation can lead to elevated levels of TNF $\alpha$ that eventually results in the progression of AD or PD pathology (Decourt et al. 2016). Cellular and molecular changes implicate increased TNF $\alpha$ levels by microglial activation in both $\mathrm{AD}$ and $\mathrm{PD}$, which suggests a commonness in TNF $\alpha$ signalling pathway in the progression of both these diseases (A Frankola et al. 2011). Several studies have indicated changes in oxidative stress due to increased level of reactive oxygen species (ROS) which was induced by TNF $\alpha$ signalling in $\mathrm{AD}$ and PD (Fischer and Maier 2015). In both $A D$ and PD conditions, accumulation of abnormal $\alpha \mathrm{S}$ and $\mathrm{A} \beta$ lead to oxidative stress that trigger the apoptotic pathway (Singh et al. 2019).

Brain's insulin sensitivity has been studied (Blázquez et al. 2014) and insulin has been known to regulate cellular mechanisms inside the brain (Plum et al. 2005). Insulin has also been documented to regulate various brain functions such as neuroprotection, synaptic plasticity, memory, and reward recognition (Ferrario et al. 2018). The cellular links between insulin resistance and neurodegeneration in PD related pathological mechanisms have been previously discussed (Athauda and Foltynie 2016). Impaired insulin signalling pathway has also been identified as a critical pathological factor 
contributing to the development of $\mathrm{AD}$ (Hölscher 2014). Impaired insulin signalling has been known to be associated to the formation of plaques, tangles, increased oxidative stress, and important factors facilitating neurodegeneration in AD ( $\operatorname{Rad}$ et al. 2018). Experimental models have shown the critical role of insulin signalling pathway in degradation of $\mathrm{A} \beta$ and $\alpha \mathrm{S}$ and blocking them led to formation of toxic fibrils and plaques (Sharma and Singh 2016). Insulin signalling and neuroinflammation may be co-related, with an imbalance possibly inducing an elevation in inflammatory cytokines including TNFo as observed during AD and PD (Yang et al. 2018). There is a need to re-analyze the roles and relationships of TNF $\alpha$ signalling, activation of glial cells, oxidative stress, insulin resistance and accumulation of misfolded/mutated protein aggregates that are linked to each other, share common genes and possibly signalling pathways, that may lead to neurodegeneration in both $\mathrm{AD}$ and $\mathrm{PD}$ pathology.

Modelling disease related signalling pathways in silico helps in understanding the experimentally-relevant relationships between individual proteins, interactions and related perturbations which are crucial for analysing disease mechanisms and for mapping appropriate therapeutic targets (Vidal et al. 2011; Hao et al. 2018). Modelling complex biological pathway networks including their cellular and molecular components, and interactions (Ji et al. 2017) can help connect critical factors statistically relevant as common signaling mechanisms or phentotypic functions to both disorders. Developing computational models can aid reproducing disease pathways and predicting dynamical behaviours essential for approprite protocol design and experimental testing and to map clinical symptoms to molecular processes going through cellular and circuit functions (Conradi et al. 2007; Bartocci and Lió 2016). Using biochemical systems theory (BST), sub-cellular reactions and biochemical pathways were modeled using ordinary differential equations (ODE) for reconstructing signalling dynamics in this study (Savageau et al. 1987). All biochemical reactions involved in disease-related signalling pathways were expressed mathematically using ODE and rate equations were computed using computational tools (Bartocci and Lió 2016).

The objective of this modeling exercise was to map major genes or proteins involved in disease mechanism, the reactions affected by the mutation of these genes and the difference in reactions when compared with healthy controls, action ofpotential drugs. In literature, BST models on oxidative stress and inflammation in insulin resistance were already available for PD condition (Braatz and Coleman 2015). These models explore some of the important pathways involved in PD and the treatment options. Most of the initial conditions for the model parameters were assigned as relative values rather than real data. With the need to model crosstalk and critical networks relevant to neurodegeneration identified by more recent studies, we have incorporated the crosstalk between insulin resistance, oxidative stress and neuroinflammation related to TNF $\alpha$ signalling in normal, AD and PD conditions (Fallahi-Sichani et al. 2011; Sasidharakurup et al. 2020; Su and Wu 2020). The parameteric values relating to biological states and initial conditions for this model were manually extracted from literature on disease models. In a previous study, we had modelled the role of TNF $\alpha$ mediated glutamate excitotoxicity and neuroinflammation (Sasidharakurup et al. 2020) and the variations in TNFa levels during both healthy and diseased conditions were analyzed. Some autocrine loops co-involved in the activation of TNF $\alpha$ were also modeled to study how TNF훼 stimulates its own release. To extend the relationships between $\mathrm{AD}$ and $\mathrm{PD}$, this present study focuses on developing a model of $\mathrm{TNF} \alpha$ related pathways regulated 
by neuroinflammation, oxidative stress and insulin resistance during neurodegeneration. In addition, few of the crucial feedback loops involved in TNF $\alpha$ signalling and their emergent properties maintaining the disease condition needed to be incorporated. Aimed towards building a tool for designing experimental interventions and connecting to clinically relevant biomarkers, common cellular components found in both $\mathrm{AD}$ and $\mathrm{PD}$ conditions, that trigger $\mathrm{TNF} \alpha$ signalling such as $\mathrm{A} \beta, \alpha \mathrm{S}$, tau phosphorylation, calcium, glutamate etc. were modelled in this paper.

\section{Methods}

Major pathways involved in TNFo signalling regulated by inflammation, oxidative stress and insulin resistance that leads to neuronal death were modelled in this paper using biochemical systems theory. Pathways were mathematically reconstructed and simulations were done by using CellDesigner (Funahashi et al. 2006). All reactions were modelled as networks with genes, proteins and other cellular components represented as nodes in the network. Reactions were inter-connected using corresponding kinetic formulae. In this reconstruction, all reactions were mathematically represented using ODE, and initial concentration values and rate constant values were assigned.

The law of mass action and Michaelis-Menten (MM) kinetics were used to approximate reaction values and to model enzyme reactions (see Eq. (1) and Eq. (2)).

\section{Michaelis-Menten kinetics}

Enzyme-involved reactions were mathematically expressed using MM kinetics.

$$
v=\frac{d[p]}{d t}=\frac{v_{\max }[s]}{k_{m}+[s]}
$$

Where, Vmax was the maximum rate achieved by the system, at saturating substrate concentration in relation of reaction rate $\mathrm{v}$ to $[\mathrm{s}]$, where [s] was the concentration of a substrate $\mathrm{S} . \mathrm{K}_{\mathrm{m}}$ was Michealis constant was the rate constant and the rate constant $\mathrm{K}_{\mathrm{m}}$ (Michaelis constant) was equal to [s] when $\mathrm{v}$ is half of $\mathrm{V}_{\max }$.

\section{Generalized mass action (GMA) kinetics}

Each reaction was approximated using the power law equation, represented as a system of ODE (Tucker et al. 2007):

$$
\dot{\mathrm{x}}_{i}=\sum_{k=1}^{n+m}\left[ \pm \gamma_{k p} \prod_{j=1}^{n} X_{j}^{f_{i j k}}\right]
$$

Where $i=(1, \ldots, d)$. Each variable $x_{i}$ represented the concentration of a reactant, and i denoted the time derivative of $x_{i}$. In the model, the parameters $\gamma_{k p}$ were rate constants, whereas the parameters $\mathrm{f}_{\mathrm{ijk}}$ were kinetic orders.

The concentrations parameters in the MM approximation and in ODEs were estimated from experimental data that have quantified by common molecular biology techniques including ELISA, western blotting, radioenzymatic assay, HPLC, mass spectrometry and the rate parameters were obtained from previous modelling or from in vitro studies on normal and diseased tissues. Table 1, reports the known critical proteins in the model of $\mathrm{AD}$ pathway, their concentration values, corresponding 
Table 1 Experimental data sources for concentrations and related literature in AD. The concentrations parameters of individual genes involved in the cellular pathways of Alzheimer's disease were adapted from experimental studies listed here.

\begin{tabular}{|c|c|c|c|c|c|c|}
\hline \multirow{2}{*}{$\begin{array}{l}\text { Protein/ } \\
\text { gene }\end{array}$} & \multirow[t]{2}{*}{ Experiment } & \multirow[t]{2}{*}{ Region } & \multirow[t]{2}{*}{ Model } & \multicolumn{2}{|l|}{ Concentration } & \multirow[t]{2}{*}{ References } \\
\hline & & & & Control & Diseased & \\
\hline TNFa & EIA assay & CSF & Humans & $22.3+9.5 \mathrm{pg} / \mathrm{ml}$ & $96.3+9.1 \mathrm{pg} / \mathrm{ml}$ & $\begin{array}{l}\text { (Mogi et al. } \\
\text { 1994) }\end{array}$ \\
\hline Tau & Sandwich ELISA & CSF & $\begin{array}{l}\text { Human } \\
\text { (in vitro) }\end{array}$ & $288 \pm 160 \mathrm{pg} / \mathrm{mL}$ & $728 \pm 432 \mathrm{pg} / \mathrm{mL}$ & $\begin{array}{l}\text { (Kester } \\
\text { et al. 2009) }\end{array}$ \\
\hline$A \beta 42$ & Sandwich ELISA & CSF & $\begin{array}{l}\text { Human } \\
\text { (in vitro) }\end{array}$ & $845 \pm 222 \mathrm{pg} / \mathrm{mL}$ & $459 \pm 170 \mathrm{pg} / \mathrm{mL}$ & $\begin{array}{l}\text { (Kester } \\
\text { et al. 2009) }\end{array}$ \\
\hline Calcium & $\begin{array}{l}\text { Inductively Coupled } \\
\text { Plasma Mass } \\
\text { Spectrometry (ICP } \\
\text { MS) }\end{array}$ & Serum & $\begin{array}{l}\text { Human } \\
\text { (in vitro) }\end{array}$ & $7.2 \pm 2.6 \mu \mathrm{g} / \mathrm{L}$ & $8.1 \pm 2.1 \mu \mathrm{g} / \mathrm{L}$ & $\begin{array}{l}\text { (Paglia } \\
\text { et al. 2016) }\end{array}$ \\
\hline APP & $\begin{array}{l}\text { SDS PAGE followed } \\
\text { by western blotting } \\
\text { and densitometric } \\
\text { scanning }\end{array}$ & Hippocampus & $\begin{array}{l}\text { Human } \\
\text { (in vitro) }\end{array}$ & $\begin{array}{l}0.98 \pm 0.32 \text { per } \\
5.0 \mu \mathrm{g} \text { protein }\end{array}$ & $\begin{array}{l}1.92 \pm 0.57 \text { per } \\
5.0 \mu \mathrm{g} \text { protein }\end{array}$ & $\begin{array}{l}\text { (Davidsson } \\
\text { et al. 2001) }\end{array}$ \\
\hline as & $\begin{array}{l}\text { Newly developed } \\
\text { bead based xMAP } \\
\text { technology assay }\end{array}$ & CSF & $\begin{array}{l}\text { Human } \\
\text { (in vitro) }\end{array}$ & $67 \mathrm{ng} / \mathrm{L}$ & 94 ng/L & $\begin{array}{l}\text { (Hansson } \\
\text { et al. 2014) }\end{array}$ \\
\hline IL-6 & $\begin{array}{l}\text { Commercial plate- } \\
\text { based ELISA }\end{array}$ & Plasma & $\begin{array}{l}\text { Human } \\
\text { (in vitro) }\end{array}$ & $\begin{array}{l}1.622 \pm 0.806 \mathrm{pg} / \\
\mathrm{mL}\end{array}$ & $\begin{array}{l}2.343 \pm 1.379 \mathrm{pg} / \\
\mathrm{mL}\end{array}$ & $\begin{array}{l}\text { (Wu et al. } \\
\text { 2015) }\end{array}$ \\
\hline NOS & $\begin{array}{l}\text { Assayed by } \\
\text { measuring } \\
\text { conversion of } \\
\text { arginine to citrulline }\end{array}$ & Microvessels & $\begin{array}{l}\text { Human } \\
\text { (in vitro) }\end{array}$ & $\begin{array}{l}10.0 \pm 2.4 \mathrm{nmol} / \\
\mathrm{min} / \mathrm{mg}\end{array}$ & $\begin{array}{l}44.7 \pm 5.5 \mathrm{nmol} / \\
\mathrm{min} / \mathrm{mg}\end{array}$ & $\begin{array}{l}\text { (Dorheim } \\
\text { et al. 1994) }\end{array}$ \\
\hline GSK-3 & EIA assay & $\begin{array}{l}\text { Post } \\
\text { Synaptosomal } \\
\text { supernatant }\end{array}$ & $\begin{array}{l}\text { Human } \\
\text { (in vitro) }\end{array}$ & $\begin{array}{l}156.41 \pm 12.07 \\
\text { pmol phosphate } \\
\text { incorporated/mg } \\
\text { protein } / \mathrm{min}\end{array}$ & $\begin{array}{l}160.78 \pm 29.6 \mathrm{pmol} \\
\text { phosphate } \\
\text { incorporated } / \mathrm{mg} \\
\text { protein/min }\end{array}$ & $\begin{array}{l}\text { (Pei et al. } \\
\text { 1997) }\end{array}$ \\
\hline
\end{tabular}

experiments, the experimental model and related literature reference. For biologically valid reconstructions, the model included the concentration values of important proteins including TNF $\alpha$ (Mogi et al. 1994), tau (Kester et al. 2009), A $\beta$ (Kester et al. 2009), calcium (Paglia et al. 2016), APP (Davidsson et al. 2001), $\alpha$ S (Hansson et al. 2014), IL-6 (Wu et al. 2015), NOS (Dorheim et al. 1994), GSK-3 (Pei et al. 1997) both in control and $\mathrm{AD}$ conditions.

Experiment-derived values (see Table 2) for concentrations of TNF $\alpha$ (Mogi et al. 1994), glutamate (Iwasaki et al. 1992), calcium (Putney and Tomita 2011), TNFR1 (de JR de Paula et al. 2009), $\alpha$ S (Oczkowska et al. 2014), ROS (Tretter and Dam-Vizi 2004), IL-1 $\beta$ (Hu et al. 2015) and tau (Blennow et al. 1995) in control and PD conditions were incorporated into the model.

Using this literature data, the biochemical networks in AD and PD have been modelled from simple reactions to generate complex networks made from proteins and other biomolecules as in experimental observations. For example, in the case of TNF $\alpha$ signalling, the emergent properties of the system (see Fig. 1) were related to three vicious circles (Olmos and Lladó 2014).. As reported earlier, initial concentration values for the model were extracted from available experimental data either from studies conducted on neurons in the post-mortem brain of patients or from experimental animal models. For example, initial concentration values for TNF $\alpha$ in case of normal and diseased conditions were taken from a study by Mogi et al. (1994) where the elevated 
Table 2 Experimental data sources for concentrations and related literature in PD. The values for modeling the concentrations of individual genes involved in the biochemical pathways of PD were adapted from experimental data listed as references

\begin{tabular}{|c|c|c|c|c|c|c|}
\hline \multirow{2}{*}{$\begin{array}{l}\text { Protein/ } \\
\text { gene } \\
\text { name }\end{array}$} & \multirow[t]{2}{*}{ Experiment } & \multirow[t]{2}{*}{ Region } & \multirow[t]{2}{*}{ Model } & \multicolumn{2}{|l|}{ Concentration } & \multirow[t]{2}{*}{ References } \\
\hline & & & & Control & Diseased & \\
\hline TNF a & $\begin{array}{l}\text { Sandwich enzyme } \\
\text { immunoassay (EIA) }\end{array}$ & CSF & $\begin{array}{l}\text { Humans } \\
\text { (in vitro) }\end{array}$ & $22.3 \pm 9.5 \mathrm{pg} / \mathrm{ml}$ & $\begin{array}{l}96.3 \pm 9.1 \mathrm{pg} / \\
\mathrm{ml}\end{array}$ & $\begin{array}{l}\text { (Mogi et al. } \\
\text { 1994) }\end{array}$ \\
\hline Glutamate & $\begin{array}{l}\text { Ion exchange } \\
\text { chromatography }\end{array}$ & $\begin{array}{l}\text { Blood } \\
\text { plasma }\end{array}$ & $\begin{array}{l}\text { Humans } \\
\text { (in vitro) }\end{array}$ & $\mathrm{L} 4.1 \pm 11.3 \mathrm{\mu mol} /$ & $\begin{array}{l}71.7 \pm 8.5 \mu \mathrm{mol} / \\
\mathrm{L}\end{array}$ & $\begin{array}{l}\text { (Iwasaki } \\
\text { et al. 1992) }\end{array}$ \\
\hline $\mathrm{Ca}^{2+}$ & Fluorometric analysis & $\begin{array}{l}\text { Substantia } \\
\text { nigra pars } \\
\text { compacta }\end{array}$ & $\begin{array}{l}\text { Sprague- } \\
\text { Dawley } \\
\text { rats. } \\
\text { (in vitro) }\end{array}$ & $0.080 \mu \mathrm{M}$ & $100 \mu \mathrm{M}$ & $\begin{array}{l}\text { (Putney and } \\
\text { Tomita } \\
\text { 2011) }\end{array}$ \\
\hline TNFR1 & ELISA & $\begin{array}{l}\text { Blood } \\
\text { serum }\end{array}$ & $\begin{array}{l}\text { Humans } \\
\text { (in vitro) }\end{array}$ & $\begin{array}{l}438.9 \pm 171.9 \mathrm{pg} / \\
\mathrm{ml}\end{array}$ & $\begin{array}{l}558.5 \pm 246.3 \\
\mathrm{pg} / \mathrm{ml}\end{array}$ & $\begin{array}{l}\text { (de JR de } \\
\text { Paula et al. } \\
\text { 2009) }\end{array}$ \\
\hline as & IMR assay & $\begin{array}{l}\text { Blood } \\
\text { plasma }\end{array}$ & $\begin{array}{l}\text { Humans } \\
\text { (in vitro) }\end{array}$ & $645.57 \mathrm{pg} / \mathrm{ml}$ & $1294.9 \mathrm{pg} / \mathrm{ml}$ & $\begin{array}{l}\text { (Oczkowska } \\
\text { et al. 2014) }\end{array}$ \\
\hline ROS & $\begin{array}{l}\text { Assay for aconitase } \\
\text { activity. Parallel assay of } \\
\text { a-KGDH activity and } \\
\text { H2O2 generation by a- } \\
\text { KGDH Statistics. }\end{array}$ & $\begin{array}{l}\text { Brain } \\
\text { cortex }\end{array}$ & $\begin{array}{l}\text { Guinea } \\
\text { Pig } \\
\text { (in vitro) }\end{array}$ & $\begin{array}{l}12.7 \mathrm{pmol} / \mathrm{min} / \\
\mathrm{mg}\end{array}$ & $\begin{array}{l}32 \mathrm{pmol} / \mathrm{min} / \\
\mathrm{mg}\end{array}$ & $\begin{array}{l}\text { (Tretter and } \\
\text { Dam-Vizi } \\
\text { 2004) }\end{array}$ \\
\hline$I L-1 \beta$ & ELISA & CSF & $\begin{array}{l}\text { Human } \\
\text { (in vitro) }\end{array}$ & $9.409 \mathrm{pg} / \mathrm{mL}$ & $11.122 \mathrm{pg} / \mathrm{mL}$ & $\begin{array}{l}\text { (Hu et al. } \\
\text { 2015) }\end{array}$ \\
\hline Tau & Sandwich ELISA & CSF & $\begin{array}{l}\text { Human } \\
\text { (in vitro) }\end{array}$ & $640 \pm 230 \mathrm{pg} / \mathrm{ml}$ & $720 \pm 590 \mathrm{pg} / \mathrm{ml}$ & $\begin{array}{l}\text { (Blennow } \\
\text { et al. 1995) }\end{array}$ \\
\hline
\end{tabular}

TNF $\alpha$ concentration level in diseased condition was measured in the striatum and cerebrospinal fluid (CSF). The concentration in CSF was noted as $22.3+9.5 \mathrm{pg} / \mathrm{ml}$ in control and $96.3+9.1 \mathrm{pg} / \mathrm{ml}$ in patients. The feedback mechanism in the production of extracellular TNF $\alpha$ involves both microglial and astrocyte TNF $\alpha$ along with their respective TNFR1 receptors (Fig. 1).

The feedback mechanisms involving TNF $\alpha$ release during inflammation can be expressed using a simple feedback loop involved in the TNF $\alpha$ pathway. In the model, the extracellular TNF $\alpha$ (exTNF $\alpha$ ) bound to microglial TNF $\alpha$ receptor (mTNFR1) and lead to the production of microglial TNFa (mTNF $\alpha$ ) inside the microglia. As in experiments, the excess TNF $\alpha$ was modeled to be released and initiated its own microglial release. exTNF $\alpha$ can also bind to its receptor expressed in astrocyte (aTNFR1) and release TNF $\alpha$ inside astrocyte $(\mathrm{aTNF} \alpha)$ which again triggers its own release. The

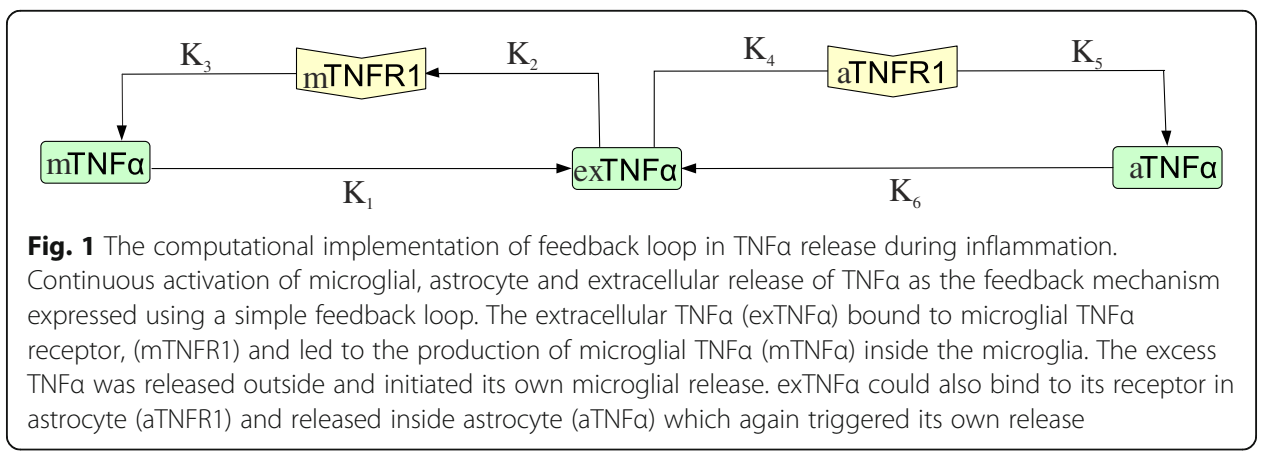


individual interactions involved were represented using mathematical equations employing kinetics law and ODE. Here, k1, k2, k3 .... k6 are the rate constants.

The individual reactions in this loop were expressed as:

$$
\begin{aligned}
& \frac{\mathrm{d}[\mathrm{mTNFR} 1]}{\mathrm{dt}}=k_{2} *[\mathrm{exTNF} \alpha]-k_{3}[\mathrm{mTNF} \alpha] \\
& \frac{\mathrm{d}[\mathrm{mTNF} \alpha]}{\mathrm{dt}}=k_{3} *[\mathrm{mTNFR} 1]-k_{1}[\mathrm{exTNF} \alpha] \\
& \frac{\mathrm{d}[\mathrm{aTNF} \alpha]}{\mathrm{dt}}=k_{5} *[\mathrm{aTNFR} 1]-k_{6}[\text { exTNF } \alpha \\
& \frac{\mathrm{d}[\mathrm{aTNFR} 1]}{\mathrm{dt}}=k_{4} *[\mathrm{exTNF} \alpha]-k_{5}[a \mathrm{TNF} \alpha] \\
& \frac{\mathrm{d}[\mathrm{exTNF} \alpha]}{\mathrm{dt}}=k_{1} *[\mathrm{mTNF} \alpha]+k_{6}[a \mathrm{TNF} \alpha]-k_{2}[m \mathrm{TNFR} 1]-k_{4}[a \mathrm{TNFR} 1]
\end{aligned}
$$

Here, extracellular TNF $\alpha \quad$ (exTNF $\alpha)$, microglial TNF $\alpha \quad$ (mTNF $\alpha)$, microglial TNFR1(mTNFR1), astroglial TNF $\alpha$ (aTNF $\alpha)$, astroglial TNFR1(TNF $\alpha)$ were the different reaction species. In a reaction, production of a new species was considered as a positive reaction whereas its degradation/release of the same/new species was a negative reaction. In this BST modelling approach, exTNF $\alpha$ binds to mTNFR1 that lead to the production of mTNF $\alpha$ inside the microglia. Here, the rate of change of mTNFR1 was mathematically represented as in Eq. (3). In the model, when mTNFR1 was considered, the reaction was exTNF $\alpha$ related. It bound to mTNFR1, which was a positive reaction and this led to the production of mTNFa inside the microglia which was modeled as a negative reaction. Similarly, rate changes of other reactions in the model were also converted to mathematical equations according to their rate equations. Here, Eq. (4) was the equation for mTNFo, Eq. (5) for aTNFo, Eq. (6) for aTNFR1 and Eq. (7) for exTNF $\alpha$ respectively. All these biochemical reactions were modelled and related concentration changes over time have been analysed. The predictions from the model were compared with previous existing reports and validated with available experimental evidence.

\section{Pathways involved in AD and PD regulated by TNFa}

\section{Emergent properties of vicious loops in TNFa}

The pathway of TNF $\alpha$ signalling (see Fig. 2) included some of the feedback loops and reactions involved in TNF $\alpha$ linked neurodegeneration. Here, activated microglia released TNF $\alpha$ which induced its own release and triggers glutamate release (Olmos and Lladó 2014). The excessive glutamate bound to its receptor on microglia which initiated further TNF $\alpha$ release in excess (Clark and Vissel 2016). In a recent study (Wang et al. 2018), on the TNF $\alpha$ in astrocytes to understand the multidrug resistance gene expression, activated astrocytes released TNF $\alpha$ and consequently it stimulated its own release. Also, it initiated astrocytes to produce excess extracellular glutamate (Mahmoud et al. 2019). In neurons, TNF $\alpha$ lead to excess calcium influx and initiated degeneration of the cells. The cross-talk between the dying neuron and microglia maintained activated microglia that released excess TNF $\alpha$ (Kuno et al. 2005; Olmos and Lladó 2014). 


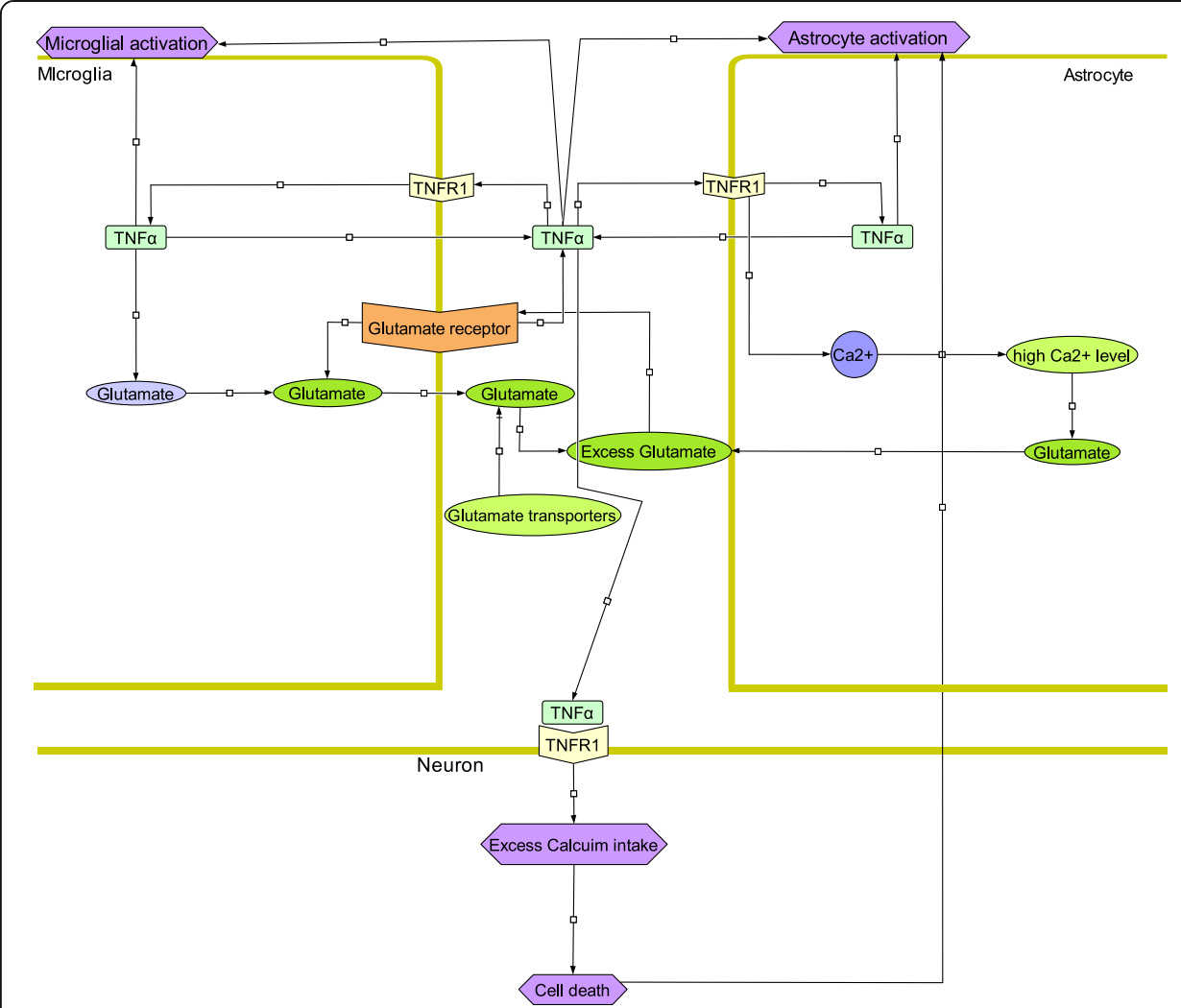

Fig. 2 Feedback loops involved in TNFa pathway related to neuroinflammation. The pathway depicts neuroinflammation induced production and release of TNFa from both microglia and astrocytes that could lead to dopaminergic cell death. Microglial release of TNFa caused its own release and initiated excess glutamate production. Excess TNFa kept microglia in the active state, which led to cellular imbalance of TNFa and glutamate. Glutamate bound to its microglial receptor and induced excess TNFa release. This prolonged activation in chronic inflammation led to rapid increase in glutamate, TNFa and other cellular factors which resulted in the damage of nearby neurons. Activated microglia also released TNFa that stimulated its own release. This initiated the production of excess extracellular glutamate that in turn induced release of TNFa. In neurons, TNFa triggers excess calcium influx which initiates pro-apoptotic factors and led to cell death. The cross-talk between the dying neuron and microglia maintained glial cells in an active state, leading to the release of TNFa

\section{Oxidative stress in AD and PD}

In our previous study (Sasidharakurup et al. 2017), we had modelled the PD-related mutated genes involved in the ROS pathway. Mutated and misfolded proteins (see Fig. 3) such as $A \beta, \alpha S$ and accumulation of its aggregates along with TNF $\alpha$ that led to the formation of ROS in AD and PD conditions were included in this model (Fischer and Maier 2015). Elevated ROS activates microglia and astrocytes. This was known to lead to cell damage and inflammation and generated a feed-forward loop of neurodegeneration (Fischer and Maier 2015). In AD, ROS activates the p38 pathway, that initiated tau phosphorylation and hyperphosphorylation that created neurofibrillary tangles, eventually leading to cell death (Niranjan 2014). In PD, $\alpha$ S activates the p38 pathway that induced TNF $\alpha$ and inflammatory cytokines in astrocytes which released cytochrome-c that produced mitochondrial oxidative stress (Yu et al. 2017). This uncontrolled process of ROS induced inflammation and TNF $\alpha-$ induced oxidative stress was a common pathway in neurodegeneration of neurons in both $\mathrm{AD}$ and $\mathrm{PD}$. 


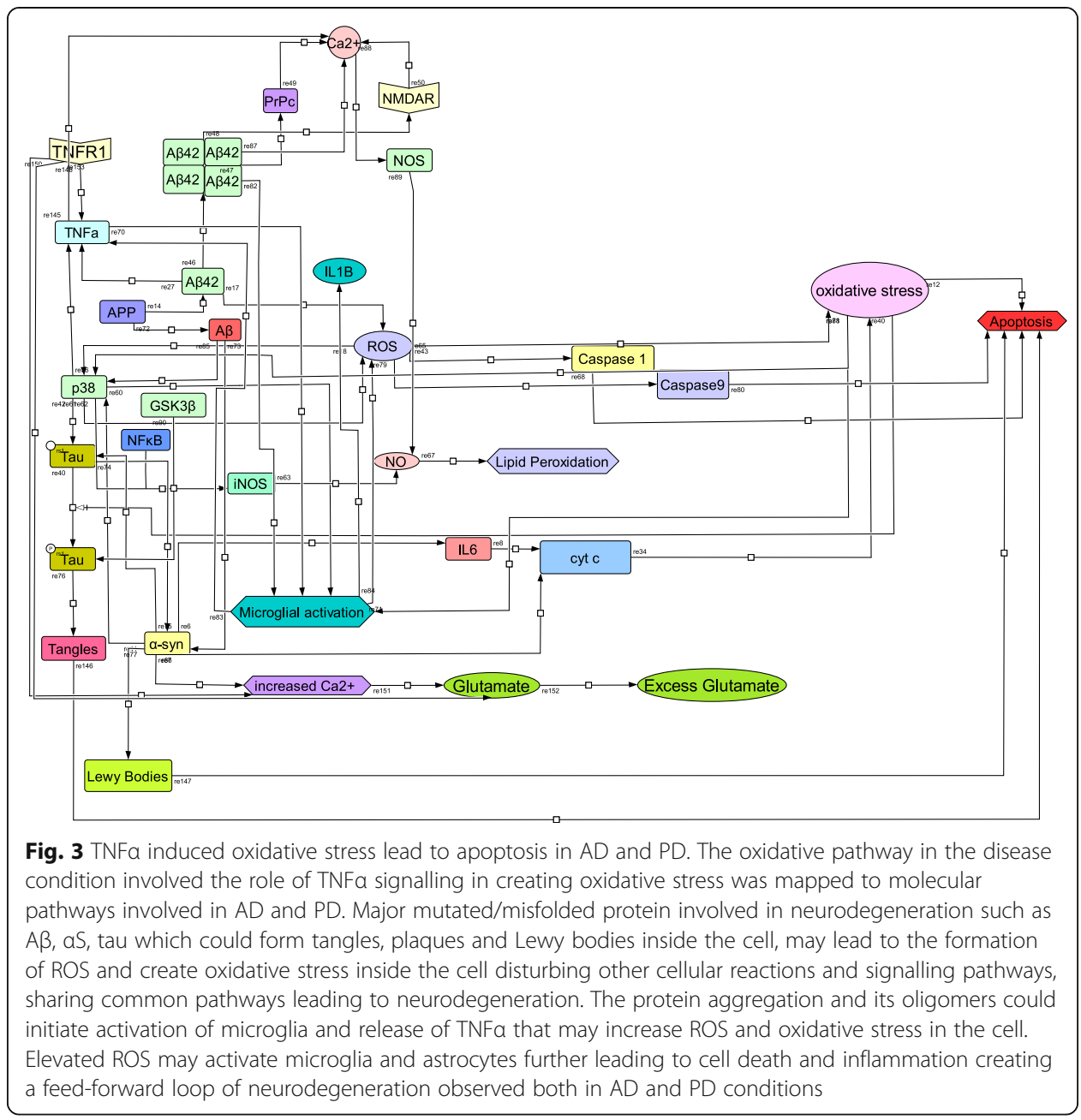

\section{Impaired insulin signalling in AD}

The signalling pathway of insulin and co-related cellular reactions involved in AD and PD were also reconstructed (see Fig. 4). Under normal condition, insulin bound to insulin receptor (IR) and initiated insulin receptor substrate - 1(IRS-1) phosphorylation that triggered PI3 kinase activation (Bedse et al. 2015). This allowed signals for other cellular processes in the normal condition such as cell growth and survival. IR activation led inward and outward flow of cellular compounds in normal condition; the metabolic reactions uptook excess components or degraded it and kept the cell functioning normally (Shetty et al. 2012). In the AD brain, accumulated $A \beta$ gets aggregated and formed oligomers that activated microglia and secreted TNF $\alpha$ along with other cytokines (Mandrekar-Colucci and Landreth 2012). Increased levels of TNF $\alpha$ and other secreted inflammatory cytokines together could inhibit the IRS-1 phosphorylation (Rehman and Akash 2016). Decreased PI3k could increase the activity of Glycogen Synthase Kinase-3 (GSK3) that resulted in phosphorylation of tau and formation of neurofibrillary tangles (Ghareeb et al. 2013). Insulin degrading enzyme (IDE) has been known to be involved in insulin and other proteasome degradation including A $\beta$ peptide (Farris et al. 2003). Insulin resistance in the brain reduced IDE which in turn increased GSK3 activity that led to formation of tangles and gradual accumulation of $A \beta$. Increased 


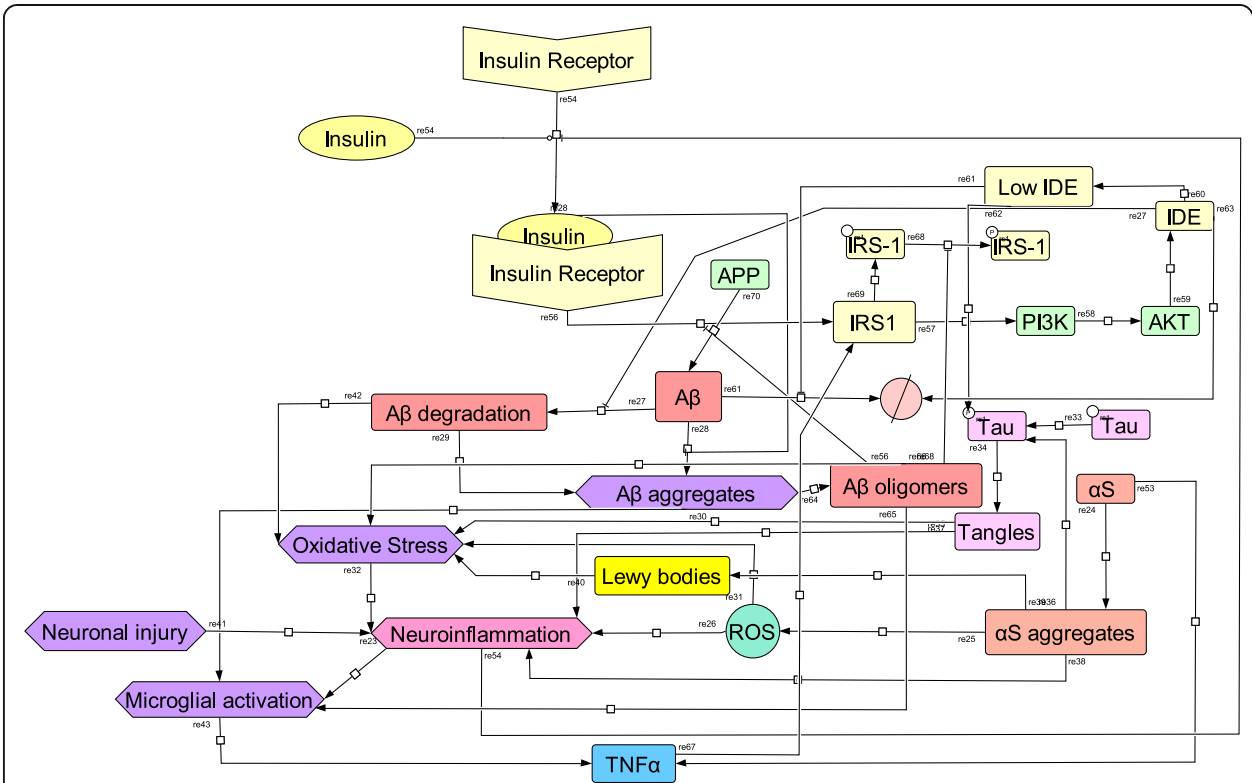

Fig. 4 Impaired insulin signalling sub-pathways in AD. Major biochemical reactions related to insulin signalling along with some of the major reactions involved in AD and PD also involve TNFa. In the AD brain, mutated $A \beta$ gets aggregated, accumulated and forms oligomers that activated microglia that secreted TNFa along with other cytokines. Similarly, activated microglia during neuroinflammation may release the same kind of inflammatory cytokines. Both these processes can jointly increase the excess TNFa release concurrently that may inhibit the IRS-1 phosphorylation. PI3k is another factor that may result in phosphorylation of tau and formation of neurofibrillary tangles in AD. Low insulin concentration in the brain reduces the IDE, an enzyme that degrades $A \beta$, which in turn leads to the formation of tangles and gradual accumulation of $A \beta$. In $A D$, soluble $A \beta$ oligomers also block IR that disturbs the normal downstream processing of insulin signalling leading to cell death. Reduced IR signalling also can affect PI3K signalling pathway and results in the upregulation of tangles and $A \beta$ formation. This may lead to the activation of microglia by increasing the level of TNFa and other cytokines, inhibits IR, and generate oxidative stress ultimately leading to cell death

GSK3 could also activate pro-apoptotic factors leading to cell death. In AD, soluble A $\beta$ oligomers also blocked IR that disturbed the normal downstream processing of insulin signalling leading to cell death (Arnold et al. 2018). Reduced IR signalling could also affect PI3k signalling pathway and resulted in down-regulation of glucose metabolism, upregulation of tangles and $A \beta$ formation (Gabbouj et al. 2019). This could activate microglia by increasing the level of TNF $\alpha$ and other cytokines, inhibiting IR, and generated oxidative stress potentially leading to cell death.

\section{Results}

\section{Neuroinflammation, oxidative stress and insulin signalling under normal condition}

The concentration levels of TNF $\alpha$, insulin, glutamate, TNFR1, calcium, ROS, $\alpha$, P38, rate of cell death and microglial activation were reconstructed (see Fig. 5). In control conditions, there was a slight increase in the level of TNF $\alpha$ and its surface receptor TNFR1 in the initial stage but decreased gradually over time. The level of insulin maintained at a constant level. A rapid drop in the level of excess glutamate and decrease in excess calcium influx was observed. The activation of 

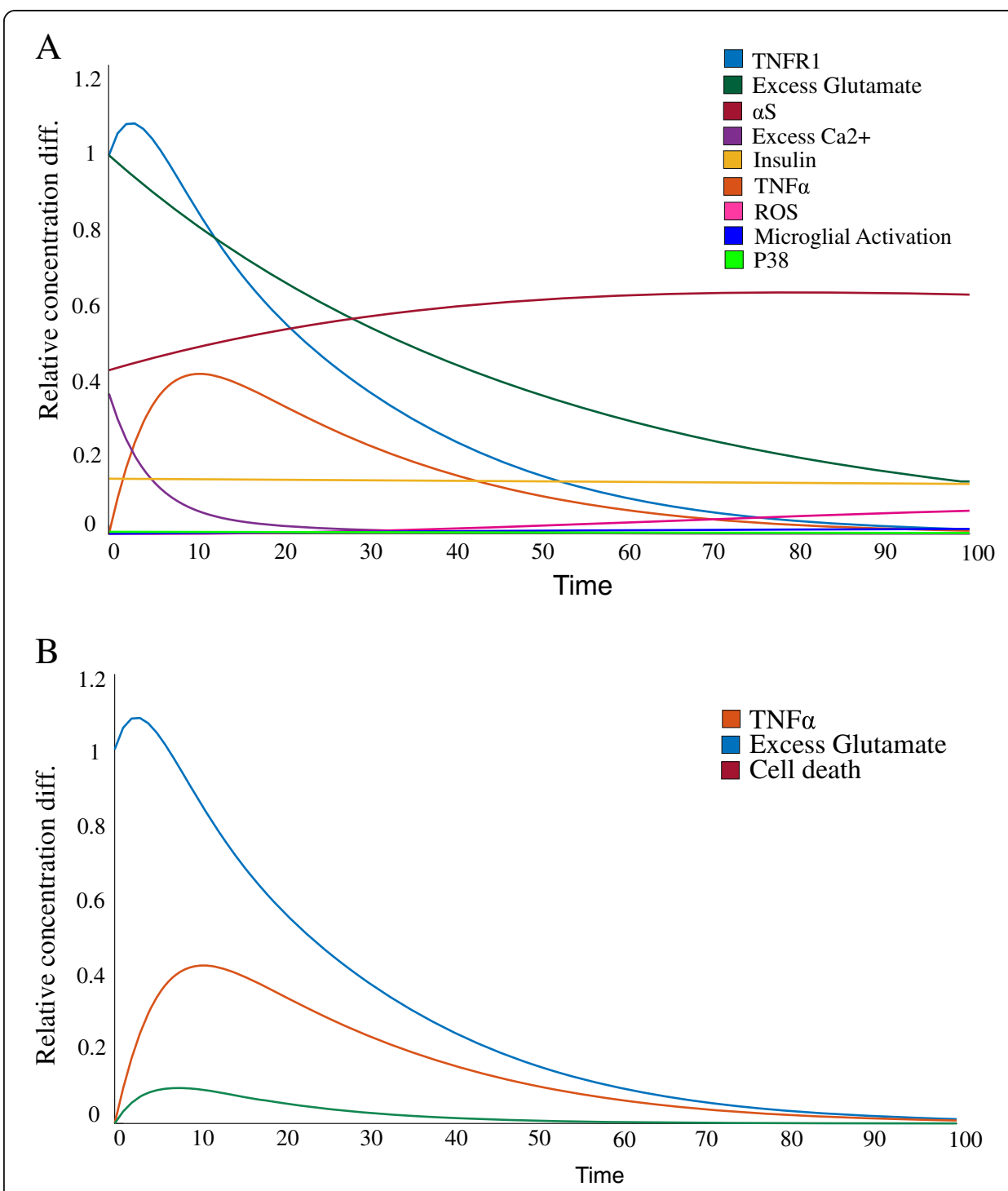

Fig. 5 Relative concentration differences in major AD/PD proteins during normal condition and variations during TNFa signalling. a Relative concentration differences of major proteins involved in neuroinflammation, oxidative stress and insulin signalling related to AD and PD in control condition. A slight increase in the level of TNF-a and its surface receptor TNFR1 in the initial stage was observed but decreased gradually with time. The insulin concentration was at a constant level. A sudden decrease in the level of excess glutamate and decrease in excess calcium influx. The activation of microglial rate and P38 level was comparatively low and rate of aS concentration was also consistent when compared to disease conditions. Both ROS formation and cell death rate were also negligibly less during the control conditions. $\mathbf{b}$ The relative concentration difference in TNFa, glutamate and rate of cell death in disease states. High concentration levels of TNFa and glutamate were observed compared to normal conditions. The feedback loops involved in TNFa release and microglial activation led to an increase in the concentration level of TNFa and glutamate from both astrocyte and microglia. Attributed to an increase in these factors, a high rate of cell death may be predicted in disease conditions

microglial rate was low compared in normal compared to diseased state. The rate of $\alpha$ S remained relatively unvarying when compared to the disease conditions. P38 level was lower and may be hypothesized as not sufficient for phosphorylation of tau protein. Both ROS formation and cell death rate were also significantly lesser in the normal condition. 
Autocrine feedback loops led to continuous activation of microglia, release of TNFa and glutamate from both astrocyte and microglia leading dopaminergic cell death

The concentration differences vary across major AD/PD related proteins under normal condition and concentration variations of proteins in TNF $\alpha$ signalling (see Fig. 5) show a difference between states. In disease state, the concentration level of TNF $\alpha$ was high compared to normal conditions. The feedback loops triggering and maintaining microglial activation led to increase in the release of glutamate from both astrocyte and microglia. In disease conditions, simulations predicted elevation in the concentration of TNF $\alpha$ together with its receptor TNFR1.

Low concentration of insulin led to inflammation, tau hyperphosphorylation, oxidative stress that could initiate apoptotic pathway and neurodegeneration

Impaired insulin pathway in $\mathrm{AD}$ and $\mathrm{PD}$ conditions (see Fig. 6) was observed as a change in the rate of $\alpha S$ aggregation and $A \beta$ plaques being elevated during diseased conditions than in normal. Insulin signalling affected the relative concentration changes in some of the key proteins involved in $\mathrm{AD}$ observed as a reduction in the insulin level compared to the control. Elevations in tau hyperphosphorylation could lead to the formation of neurofibrillary tangles observed during $\mathrm{AD}$ conditions. Compared to control, the concentration levels of $\alpha \mathrm{S}$ aggregation, Lewy bodies and $A \beta$ plaques were also high in diseased state. Since $\alpha \mathrm{S}$ aggregates and $\mathrm{A} \beta$ plaques could promote tau phosphorylation and Lewy body formation that resulted in cell death, model replicates key players maintaining high levels of inflammation which may consequently promoted impaired insulin signalling in diseased condition and also triggered apoptotic factors that led to cell death. The relative concentration levels of ROS remain modified as tau and Lewy body levels increased suggesting elevations in protein aggregation as mechanisms led to inflammation, oxidative stress and impaired insulin signalling during $\mathrm{AD}$ and $\mathrm{PD}$ conditions.

\section{Role of oxidative stress in TNFa signalling and microglial activation}

The role of oxidative stress in TNF $\alpha$ signalling pathway was modelled and relative concentration differences in cellular factors involved in AD and PD was reconstructed (see Fig. 7). Elevation in the concentration levels of TNF $\alpha$, inflammatory cytokines, tau protein and A $\beta$ in $\mathrm{AD}$ condition when compared to normal condition. Due to this enhancement, an increased activation of microglia was observed. The elevated level of misfolded and phosphorylated tau attributed in the formation of tangles and plaques compared to control. Consequently, this resulted in an increase in NOS and ROS that led to neurodegeneration. A high level of $\alpha S$ aggregation was noted during the PD condition. The level of TNF $\alpha$, IL$1 \beta$ and release of cytochrome $c$ was also observed. The production of ROS and microglial activation increased more than in control.

\section{Model validation and evaluation of biological loops}

Based on literature, all the connections between reactions in the modelled pathways were established and validated with published data from fluorometric analysis, ELISA, IMR assay, ion exchange chromatography, western blotting. For example, in the biochemical reactions involving TNF $\alpha$ induced ROS production, activation of the p38 pathway by $\alpha S$ induced TNF $\alpha$ that produced mitochondrial oxidative stress as in the experimental studies by (Schäfers et al. 2003) which shows TNF $\alpha$ activated p38 in rats 


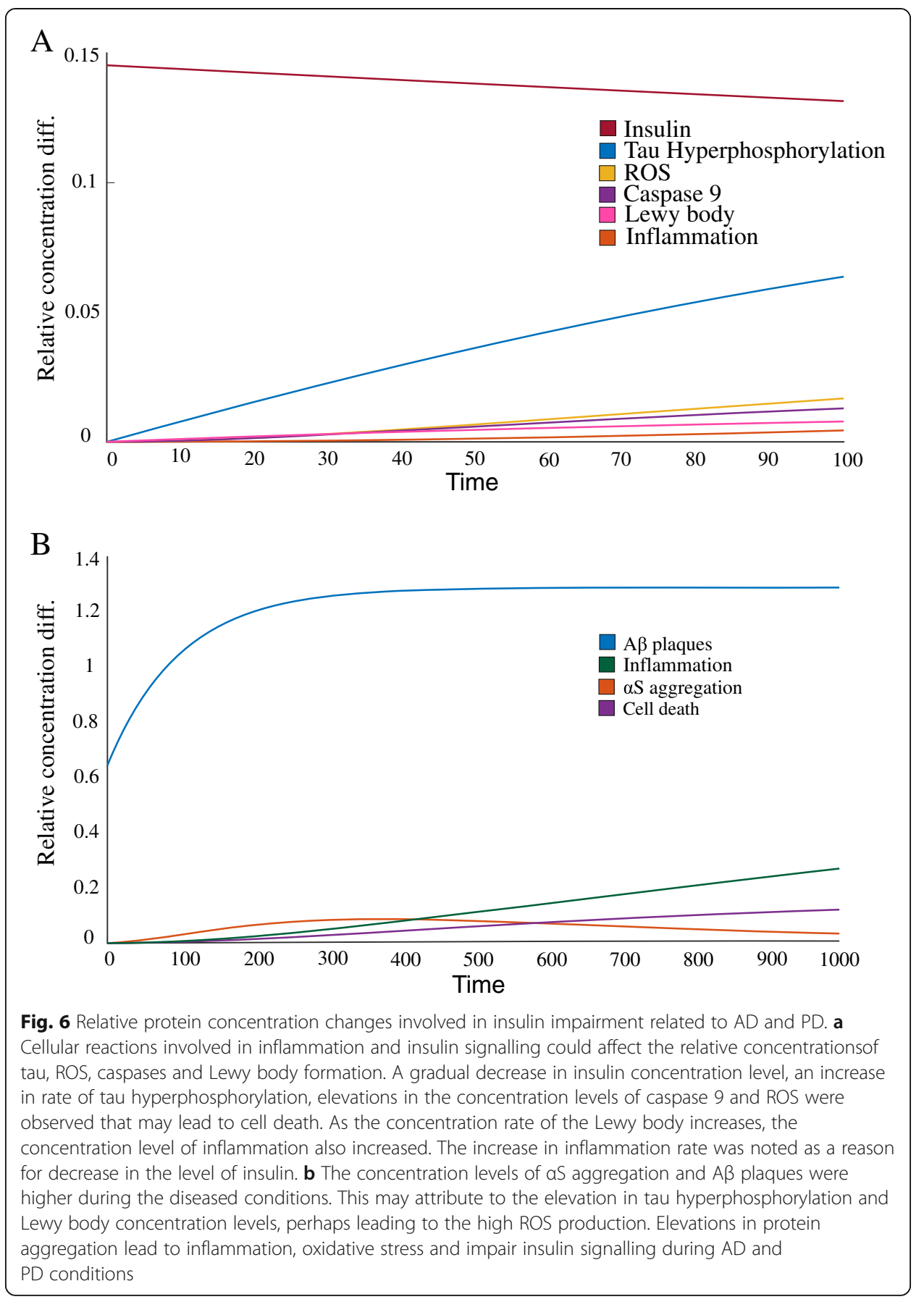

using Western blot assays and immunohistochemistry. Another study by (Sidoti-De Fraisse et al. 1998) had shown evidence on the role of mitochondria and ROS in TNF $\alpha$ induced cell death. The experiment was done in HeLa cells and analyzed using flow cytometry and fluorescence methods. The model describes correlation between GSK3 $\beta$ and tau phosphorylation, which was validated against the experimental studies by (Duka et al. 2009), where it wass shown that GSK3 $\beta$ catalyses the formation of $\alpha \mathrm{S}$ oligomers and these oligomers in turn helped to activate GSK3 $\beta$. This activated form again helps in tau hyperphosphorylation. The inter- 


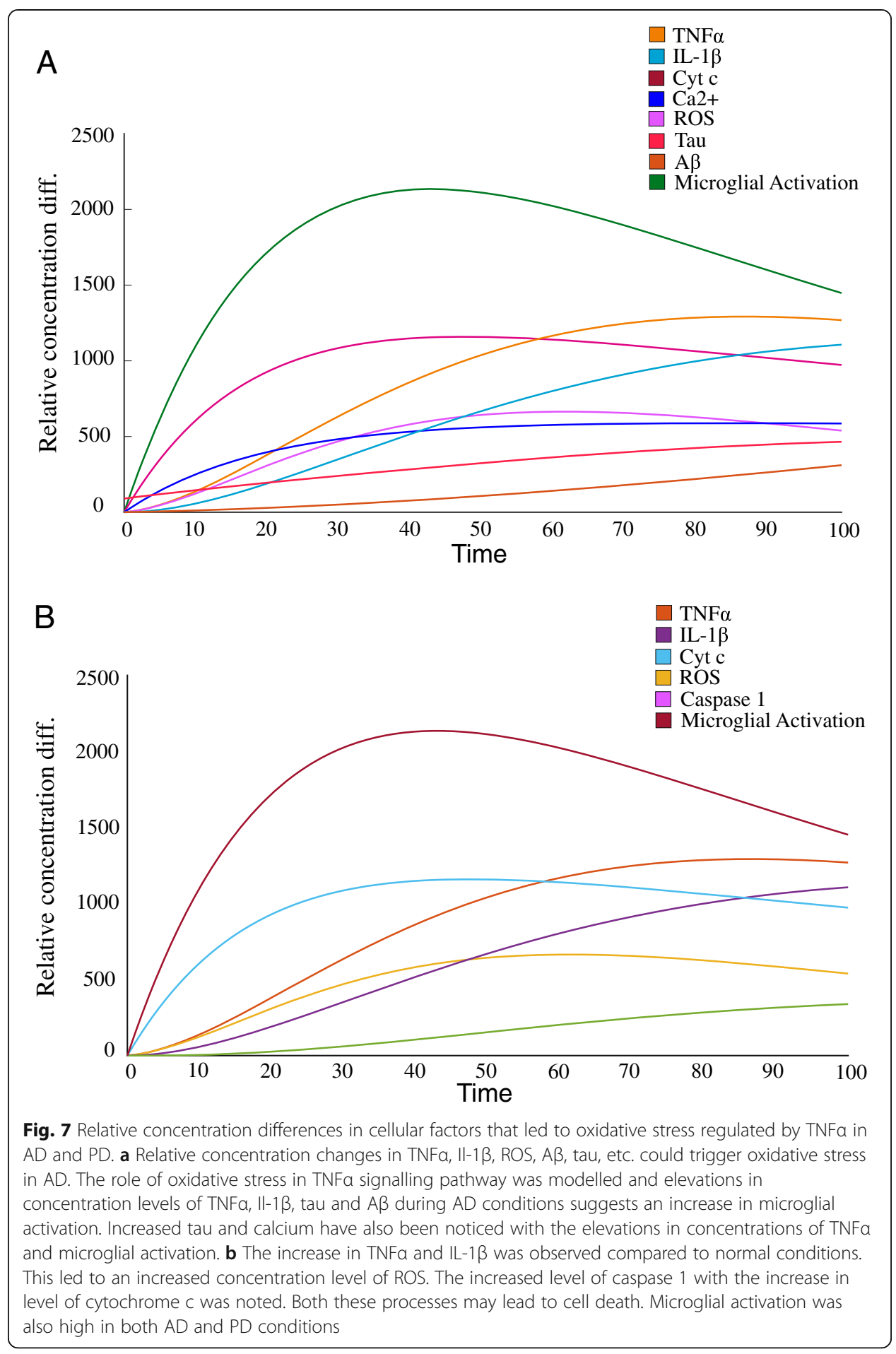

relations between these proteins was demonstrated by co-precipitating $\alpha$-synuclein with tau and GSK3 $\beta$ by GST pull down assay and western blotting (Kawakami et al. 2011). The study had reported the interaction of $\alpha \mathrm{S}$ with both tau and GSK$3 \beta$. Similarly, all the interactions and correlations between biochemical reactions modelled in this study were validated by comparing with published experimental data. 
Concentration variations of some of the reactions and interactions suggested by this model were validated with evidence from both existing experimental and computational models. In this model, simulation suggested high concentration levels in diseased conditions than in control. An experimental study measuring the TNF $\alpha$ levels in the striatum and CSF of both control and PD brains by sandwich enzyme immunoassay (Mogi et al. 1994) had reported that TNF $\alpha$ levels were significantly higher in PD than in control. Elevations in concentration changes of TNFa and its receptor has also been observed in this model according to the feedback mechanism that might be attributed to diseased states as observed in previous computational models (Anderson et al. 2015). Other computational models also have evidence showing increase in the extracellular TNF $\alpha$ and its receptor concentrations could result in negative regulation of other signaling pathways involved in inflammation and apoptosis (Fallahi-Sichani et al. 2011; Su and $\mathrm{Wu}$ 2020). In diseased conditions, simulations showed elevations in the concentration of TNF $\alpha$ together with its receptor TNFR1. Experimental studies have also observed that the feedback interaction of TNF $\alpha$ with its receptor TNFR1 induced its own release (Olmos and Lladó 2014). Both experimental and computational studies supported prolonged activation of microglia release proinflammatory cytokines including TNFa and interleukins that disrupted the downstream cellular signaling processes that could cause cell death as suggested in this model (A Frankola et al. 2011; Anderson et al. 2015; Cilfone et al. 2015). TNF $\alpha$ regulated oxidative stress response, and changes in related proteins and other factors also have been modelled and validated with existing evidence from both experimental and computational models (Braatz and Coleman 2015; Fischer and Maier 2015). Simulations suggested a low concentration of insulin led to inflammation and oxidative stress. A recent computational study by (Smith and Shanley 2013) reproduced multiple experimental observations demonstrating regulation of insulin signaling by oxidative stress that led to cell death as predicted by this model.

In this model, we had reconstructed three subnetworks associated with TNF $\alpha$ signalling (inflammation, oxidative stress and insulin signalling), where the emergent properties of these subnetworks could developed the onset and progression of $\mathrm{AD}$ and PD. The critical reactions associated with these subnetworks included abnormal aggregations of $\alpha \mathrm{S}, \mathrm{A} \beta$ and tau, the major cellular components associated with the pathophysiology of both $\mathrm{AD}$ and $\mathrm{PD}$. The simulations suggested abnormal aggregation of these proteins along with TNFa could induce oxidative stress, inflammation and insulin resistance in the brain. Simulations showed high concentration levels of $\alpha \mathrm{S}$ aggregation and $A \beta$ plaques during diseased conditions. Aggregation and oligomerization under varying concentrations of reactants were modeled. The concentration levels of $A \beta$ plaques, aggregation of $\alpha \mathrm{S}$ and tau hyperphosphorylation increased with respect to time in diseased conditions compared to control, as observed in experiments, suggesting the robustness of this model. The concentration change could further lead to inflammation, oxidative stress and insulin resistance that in turn released excess TNF $\alpha$ initiating stress and inflammation creating a feedback loop of neurodegeneration as observed in experimental studies (Mandrekar-Colucci and Landreth 2012; Fischer and Maier 2015).

\section{Discussion}

Although the role of TNF $\alpha$ pathways were independently associated with neuroinflammation, oxidative stress and insulin signalling, the involvement of autocrine loops and 
interdependency of biochemical reactions and their correlations in disease onset and progression, as modeled in this study, are critical to understand AD, PD and neurodegeneration.

In this study, the contribution of cellular reactions involved in the pathways related to the neurodegeneration processes that leads to Alzheimer's and Parkinson's have been modelled to understand the emergent properties. The modelling shows that mutations in some of the proteins such as $\alpha \mathrm{S}, \mathrm{A} \beta$ and tau share common pathophysiology in both AD and PD. These proteins along with TNF $\alpha$, ROS and other kinases can induce oxidative stress in neurons that trigger apoptotic pathways. Simulations suggested insulin was a key factor that could trigger and modulated common signalling pathways observed in AD and PD such as neuroinflammation and oxidative stress. It is also associated with the variations in cellular concentrations of $\alpha \mathrm{S}, \mathrm{A} \beta$ and tau and led to accumulation of toxic cellular oligomers.

Several factors led to microglial activation. and included TNF $\alpha$, suggesting the role of TNFa-induced neuroinflammation in activation of glial cells that lead to neurodegeneration. The simulations also highlight feedback loops, oxidative stress and insulin pathway in the brain regulated by TNF $\alpha$. Feedback interaction of TNF $\alpha$ with its receptor TNFR1 induced its own release matching experimental studies (Olmos and Lladó 2014). Increased concentrations in TNF $\alpha$ and its receptor due to the feedback mechanism could be attributed to diseased states. Increases in the level of TNF $\alpha$ in the model led to production of excess glutamate that consequently led to an increase in TNF $\alpha$ concentration level has been observed.

In neurological conditions, simulations suggested a prolonged activation of microglia. Although TNF $\alpha$ and other cytokines come to homeostasis inside cells in time, glial cells can stay active for a longer period. In diseased condition, this prolonged activation of microglia may lead to a release of proinflammatory cytokines including TNF $\alpha$ and interleukin 6 beta (IL-6B) that could disrupt the downstream cellular signalling processes leading to cell death as suggested in experiments (A Frankola et al. 2011). Like relevant clincal markers. Simulations showedelevated levels of mutated $\mathrm{AD}$ and $\mathrm{PD}$ related protein aggregation in diseased conditions compared to normal conditions. A high level of $\alpha \mathrm{S}, \mathrm{A} \beta$ and tau protein; key factors in the formation of fibrils, plaques and tangles were related and could induce oxidative stress in the cell. Increase in concentration levels of TNF $\alpha$, IL-1 $\beta$ and calcium levels have also been observed in diseased conditions. This could be the attributed cause of activating microglia and could lead to production of TNF $\alpha$ and IL-1 $\beta$, as indicated in simulations.

The insulin signalling pathway in the brain is regulated by cross-talk between several other signalling pathways including TNF $\alpha$ signalling leading to neuroinflammation and oxidative stress. Along with major mutated proteins in $\mathrm{AD} / \mathrm{PD}$ such as $\alpha \mathrm{S}, \mathrm{A} \beta$ and tau, dysregulation in these signalling pathways can cause an insulin resistance in the brain. The results also have shown an increased level of ROS in diseased state. The simulations suggest low insulin could lead to high inflammation rate, oxidative stress and cell death when compared to control. It may be predicted that TNF $\alpha$, ROS and insulin act as reliable biomarkers for both PD and AD.

The control condition may be indicative of the relative concentration changes in TNFa, insulin, glutamate, TNFR1, calcium, ROS, $\alpha$ S, P38, microglial activation and rate of cell death. This may be used as a prediction template for $\mathrm{AD} / \mathrm{PD}$ relating conditions of neuroinflammation, oxidative stress and insulin resistance. When compared to diseased state, rate of microglial activation, $\alpha \mathrm{S}, \mathrm{A} \beta, \mathrm{P} 38$, ROS formation and cell death rate, tau hyperphosphorylation, oxidative stress and cell death were considerably low. 
Given all the three conditions (inflammation, oxidative stress and insulin resistance), diseased state can be identified with high concentration elevations in TNF $\alpha, \alpha S, A \beta$ and tau compared to control. Given the correlations among the feedback loops, PD can be distinguished from normal conditions through high relative concentration differences in TNFa, glutamate, calcium and rate of cell death during neuroinflammation compared to control. In diseased state models associated with oxidative stress, there could be high activation of microglia, increased concentration levels of calcium, ROS, cytochrome c, and proinflammatory caspases was observed compared to control. Insulin involvement in disease state can be identified with high inflammation rate, oxidative stress and cell death compared to control.

The predictions relate experimentally observed concentrations to parameters seen during clinical measurements. The study correlated $A \beta$ toxicity to potential clinical features such as delusions, hallucinations, seizures attributed with tau toxicity. This matches with recent studies; both familial and sporadic PD patients report symptoms related genes indicating abnormal accumulation of $\alpha S, A \beta$, tau toxicity and other neuroinflammatory cytokines as mentioned in this model and hence the model can be used to predict changes in biomarkers for both prodromal and preclinical diagnosis of the disease (Popescu 2016; He et al. 2018). This model may serve as a design framework for altering experimental interventions. Although cerebro-spinal fluid was the main source of data for several parameters related to initial conditions, given the predictions from the data it may relate to changes in substantia nigra, blood, serum, blood plasma, brain cortex and hippocampus for labelling and further analysis.

\section{Conclusion}

This study extends current modeling studies on TNF $\alpha$ mediated glutamate excitotoxicity and neuroinflammation in PD, and a computational model to analyse TNFa signalling pathway was reconstructed to understand how inflammation, oxidative stress and insulin resistance are related to each other in neurodegeneration developing diseases such as $\mathrm{AD}$ and $\mathrm{PD}$. The model closely reconstructs known pathways of biomarkers of chronic neuroinflammation, oxidative stress and insulin signalling that are co-involved in AD and PD. Validation of the autocrine loop-related predictions need further laboratory experiments to be carried out and mapping symptoms to concentration changes that may need an extensive analysis of model's biochemical reactions and their disruptions leading to neurodegeneration.

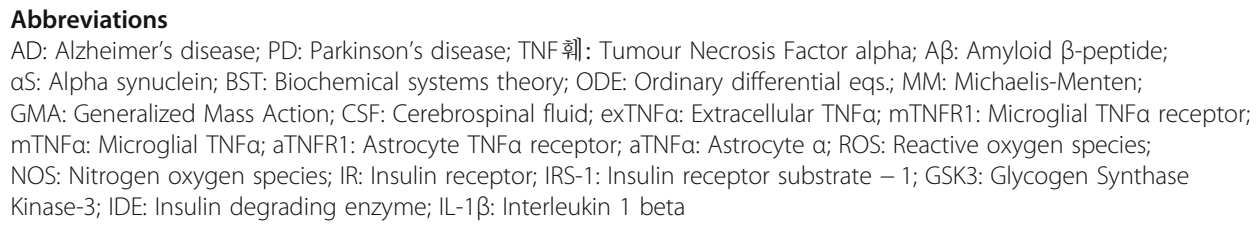

This work derives direction and ideas from the Chancellor of Amrita Vishwa Vidyapeetham, Sri Mata Amritanandamayi Devi. The authors acknowledge undergraduate student interns, Kanishka Bhaskar, Lakshmi Nair, Meera Nair, Namitha Nalarajan, Arathy Koranath and Shibin Mubarak for their contributions in this article. 


\section{Funding}

This study was partially supported by the Department of Science and Technology Grant DST/CSRI/2017/31, Government of India.

\section{Competing interests}

The authors declare that they have no competing interests.

Received: 22 April 2020 Accepted: 12 August 2020

Published online: 25 September 2020

\section{References}

A Frankola K, H Greig N, Luo W, Tweedie D (2011) Targeting TNF-alpha to elucidate and ameliorate Neuroinflammation in neurodegenerative diseases. CNS Neurol Disord - Drug Targets 10:391-403. https://doi.org/10.2174/187152711794653751

Amor S, Puentes F, Baker D, Van Der Valk P (2010) Inflammation in neurodegenerative diseases. Immunology 129:154-169. https://doi.org/10.1111/j.1365-2567.2009.03225.x

Anderson WD, Makadia HK, Greenhalgh AD et al (2015) Computational modeling of cytokine signaling in microglia. Mol BioSyst 11:3332-3346. https://doi.org/10.1039/c5mb00488h

Arnold SE, Arvanitakis Z, Macauley-Rambach SL et al (2018) Brain insulin resistance in type 2 diabetes and Alzheimer disease: concepts and conundrums. Nat Rev Neurol 14:168-181. https://doi.org/10.1038/nrneurol.2017.185

Athauda D, Foltynie T (2016) Insulin resistance and Parkinson's disease: a new target for disease modification? Prog Neurobiol 145-146:98-120. https://doi.org/10.1016/j.pneurobio.2016.10.001

Bartocci E, Lió P (2016) Computational modeling, formal analysis, and tools for systems biology. PLoS Comput Biol 12 e1004591. https://doi.org/10.1371/journal.pcbi.1004591

Bedse G, Di Domenico F, Serviddio G, Cassano T (2015) Aberrant insulin signaling in Alzheimer's disease: current knowledge. Front Neurosci 9. https://doi.org/10.3389/fnins.2015.00204

Bendor J, Logan T, Edwards RH (2013) The function of a-Synuclein. https://doi.org/10.1016/j.neuron.2013.09.004

Blázquez E, Velázquez E, Hurtado-Carneiro V, Ruiz-Albusac JM (2014) Insulin in the brain: its pathophysiological implications for states related with central insulin resistance, type 2 diabetes and alzheimer's disease. Front Endocrinol (Lausanne) 5: 1-21. https://doi.org/10.3389/fendo.2014.00161

Blennow K, Wallin A, Ågren H et al (1995) Tau protein in cerebrospinal fluid - a biochemical marker for axonal degeneration in Alzheimer disease? Mol Chem Neuropathol 26:231-245. https://doi.org/10.1007/BF02815140

Braatz EM, Coleman RA (2015) A mathematical model of insulin resistance in Parkinson's disease. Comput Biol Chem 56:8497. https://doi.org/10.1016/j.compbiolchem.2015.04.003

Chang R, Yee K-L, Sumbria RK (2017) Tumor necrosis factor a inhibition for Alzheimer's disease. J Cent Nerv Syst Dis 9 : 117957351770927. https://doi.org/10.1177/1179573517709278

Cilfone NA, Ford CB, Marino S et al (2015) Computational modeling predicts IL-10 control of lesion sterilization by balancing early host immunity-mediated antimicrobial responses with caseation during mycobacterium tuberculosis infection. J Immunol 194:664-677. https://doi.org/10.4049/jimmunol.1400734

Clark IA, Vissel B (2016) Excess cerebral TNF causing glutamate excitotoxicity rationalizes treatment of neurodegenerative diseases and neurogenic pain by anti-TNF agents. J Neuroinflammation 13. https://doi.org/10.1186/s12974-016-0708-2

Conradi C, Flockerzi D, Raisch J, Stelling J (2007) Subnetwork analysis reveals dynamic features of complex (bio) chemical networks. Proc Natl Acad Sci U S A 104:19175-19180. https://doi.org/10.1073/pnas.0705731104

Davidsson P, Bogdanovic N, Lannfelt L, Blennow K (2001) Reduced expression of amyloid precursor protein, presenilin-1 and rab3a in cortical brain regions in Alzheimer's disease. Dement Geriatr Cogn Disord 12:243-250. https://doi.org/10.1159/000051266

de JR de Paula V, Guimarães FM, Diniz BS, Forlenza OV (2009) Neurobiological pathways to Alzheimer's disease: amyloid-beta, TAU protein or both? Dement Neuropsychol 3:188-194. https://doi.org/10.1590/s1980-57642009dn30300003

Decourt B, Lahiri D, Sabbagh M (2016) Targeting tumor necrosis factor alpha for Alzheimer's disease. Curr Alzheimer Res 13 1-1. https://doi.org/10.2174/1567205013666160930110551

DeMaagd G, Philip A (2015) Parkinson's disease and its management: part 1: disease entity, risk factors, pathophysiology, clinical presentation, and diagnosis. P T 40:504-532

Dorheim MA, Tracey WR, Pollock JS, Grammas P (1994) Nitric oxide synthase activity is elevated in brain microvessels in alzheimer's disease. Biochem Biophys Res Commun 205:659-665

Duka T, Duka V, Joyce JN, Sidhu A (2009) a-Synuclein contributes to GSK-3ß-catalyzed tau phosphorylation in Parkinson's disease models. FASEB J 23:2820-2830. https://doi.org/10.1096/fj.08-120410

Esparza TJ, Wildburger NC, Jiang H et al (2016) Soluble amyloid-beta aggregates from human Alzheimer's disease brains. Sci Rep 6:1-16. https://doi.org/10.1038/srep38187

Fallahi-Sichani M, El-Kebir M, Marino S et al (2011) Multiscale computational modeling reveals a critical role for TNF-a receptor 1 dynamics in tuberculosis granuloma formation. J Immunol 186:3472-3483. https://doi.org/10.4049/jimmunol.1003299

Farris W, Mansourian S, Chang Y et al (2003) Insulin-degrading enzyme regulates the levels of insulin, amyloid $\beta$-protein, and the $\beta$-amyloid precursor protein intracellular domain in vivo. Proc Natl Acad Sci U S A 100:4162-4167. https:/doi.org/10.1073/pnas.0230450100

Ferrario CR, Reagan LP, Dorn WJB (2018) Insulin-mediated synaptic plasticity in the CNS: anatomical, functional and temporal contexts HHS public access. Neuropharmacology 136:182-191. https://doi.org/10.1016/j.neuropharm.2017.12.001

Ferreira ST, Lourenco MV, Oliveira MM, De Felice FG (2015) Soluble amyloid- $\beta$ oligomers as synaptotoxins leading to cognitive impairment in Alzheimer's disease. Front Cell Neurosci 9:1-17. https://doi.org/10.3389/fncel.2015.00191

Fischer R, Maier O (2015) Interrelation of oxidative stress and inflammation in neurodegenerative disease: role of TNF. Oxidative Med Cell Longev 2015:1-18

Funahashi A, Matsuoka Y, Jouraku A et al (2006) Celldesigner: a modeling tool for biochemical networks. In: Proceedings of the 38th conference on winter simulation, pp 1707-1712

Gabbouj S, Ryhänen S, Marttinen M et al (2019) Altered insulin signaling in Alzheimer's disease brain-special emphasis on pi3k-akt pathway. Front Neurosci 13. https://doi.org/10.3389/fnins.2019.00629 
Ghareeb DA, Mohamed S, El-Sayed M (2013) The interrelationship between insulin resistane and Alzheimer development. J Biomed Sci Eng 06:754-773. https://doi.org/10.4236/jbise.2013.67093

Giorgetti S, Greco C, Tortora P, Aprile FA (2018) Targeting amyloid aggregation: an overview of strategies and mechanisms. Int J Mol Sci 19. https://doi.org/10.3390/ijms19092677

Golde TE, Borchelt DR, Giasson BI, Lewis J (2013) Thinking laterally about neurodegenerative proteinopathies. J Clin Invest 123:1847-1855. https://doi.org/10.1172/JCl66029

Hansson O, Hall S, Öhrfelt A et al (2014) Levels of cerebrospinal fluid a-synuclein oligomers are increased in Parkinson's disease with dementia and dementia with Lewy bodies compared to Alzheimer's disease. Alzheimers Res Ther 6:4-9. https://doi.org/10.1186/alzrt255

Hao T, Wang Q, Zhao L et al (2018) Analyzing of molecular networks for human diseases and drug discovery. Curr Top Med Chem 18:1007-1014. https://doi.org/10.2174/1568026618666180813143408

Hardebo JE, Owman C (1980) Barrier mechanisms for neurotransmitter monoamines and their precursors at the blood-brain interface. Ann Neurol 8:1-11. https://doi.org/10.1002/ana.410080102

He R, Yan X, Guo J et al (2018) Recent advances in biomarkers for Parkinson's disease. Front Aging Neurosci 10

Hölscher C (2014) Drugs developed for treatment of diabetes show protective effects in Alzheimer's and Parkinson's diseases. Sheng Li Xue Bao 66:497-510. https://doi.org/10.13294/j.aps.2014.0059

Hu Y, Yu SY, Zuo LJ et al (2015) Investigation on abnormal iron metabolism and related inflammation in Parkinson disease patients with probable RBD. PLoS One 10:1-13. https://doi.org/10.1371/journal.pone.0138997

Iwasaki Y, Ikeda K, Shiojima T, Kinoshita M (1992) Increased plasma concentrations of aspartate, glutamate and glycine in Parkinson's disease. Neurosci Lett 145:175-177. https://doi.org/10.1016/0304-3940(92)90015-Y

Jahn H (2013) Memory loss in alzheimer's disease. Dialogues Clin Neurosci 15:445-454

Ji Z, Yan K, Li W et al (2017) Mathematical and computational modeling in complex biological systems. Biomed Res Int 2017: 1-16. https://doi.org/10.1155/2017/5958321

Kawakami F, Suzuki M, Shimada N et al (2011) Stimulatory effect of a -synuclein on the tau-phosphorylation by GSK-3 $\beta$. FEBS J 278:4895-4904. https://doi.org/10.1111/j.1742-4658.2011.08389.x

Kester Ml, Blankenstein MA, Bouwman FH et al (2009) CSF biomarkers in alzheimer's disease and controls: associations with apoe genotype are modified by age. J Alzheimers Dis 16:601-607. https://doi.org/10.3233/JAD-2009-0999

Killin LOJ, Starr JM, Shiue IJ, Russ TC (2016) Environmental risk factors for dementia: a systematic review. BMC Geriatr 16:1-28. https://doi.org/10.1186/s12877-016-0342-y

Kuno R, Wang J, Kawanokuchi J et al (2005) Autocrine activation of microglia by tumor necrosis factor-a. J Neuroimmunol 162:89-96. https://doi.org/10.1016/j.jneuroim.2005.01.015

Li W, Lesuisse C, Xu Y et al (2004) Stabilization of a-synuclein protein with aging and familial Parkinson's disease-linked A53T mutation. J Neurosci 24:7400-7409. https://doi.org/10.1523/JNEUROSCI.1370-04.2004

Liberman AC, Trias E, Da Silva CL et al (2019) Neuroimmune and inflammatory signals in complex disorders of the central nervous system. Neuroimmunomodulation 25:246-270. https://doi.org/10.1159/000494761

Mahlknecht P, Seppi K, Poewe W (2015) The concept of prodromal Parkinson's disease. J Parkinsons Dis 5:681-697. https:// doi.org/10.3233/JPD-150685

Mahmoud S, Gharagozloo M, Simard C, Gris D (2019) Astrocytes maintain glutamate homeostasis in the CNS by controlling the balance between glutamate uptake and release. Cells 8:184. https://doi.org/10.3390/cells8020184

Mandrekar-Colucci S, Landreth GE (2012) Microglia and inflammation in Alzheimers disease. CNS Neurol Disord - Drug Targets 9:156-167. https://doi.org/10.2174/187152710791012071

Mhyre TR, Boyd JT, Hamill RW, Maguire-Zeiss KA (2012) Parkinson's disease. Subcell Biochem 65:389-455. https://doi.org/10. 1007/978-94-007-5416-4_16

Mogi M, Harada M, Riederer P et al (1994) Tumor necrosis factor-a (TNF-a) increases both in the brain and in the cerebrospinal fluid from parkinsonian patients. Neurosci Lett 165:208-210. https://doi.org/10.1016/03043940(94)90746-3

Montgomery SL, Bowers WJ (2012) Tumor necrosis factor-alpha and the roles it plays in homeostatic and degenerative processes within the central nervous system. J Neurolmmune Pharmacol 7:42-59. https://doi.org/10.1007/s11481-011-9287-2

Murphy MP, Levine H (2010) Alzheimer's disease and the amyloid- $\beta$ peptide. J Alzheimers Dis 19:311-323. https://doi.org/10. $3233 / J A D-2010-1221$

Niranjan R (2014) The role of inflammatory and oxidative stress mechanisms in the pathogenesis of parkinson's disease: focus on astrocytes. Mol Neurobiol 49:28-38. https://doi.org/10.1007/s12035-013-8483-x

Oczkowska A, Kozubski W, Lianeri M, Dorszewska J (2014) Mutations in PRKN and SNCA Genes Important for the Progress of Parkinson's Disease. Curr Genomics. 14:502-517. https://doi.org/10.2174/1389202914666131210205839

Olmos G, Lladó J (2014) Tumor necrosis factor alpha: a link between neuroinflammation and excitotoxicity. Mediat Inflamm 2014:861231

Padmanabhan K, Nudelman K, Harenberg S et al (2017) Characterizing gene and protein crosstalks in subjects at risk of developing Alzheimer's disease: a new computational approach. Processes 5. https://doi.org/10.3390/pr5030047

Paglia G, Miedico O, Cristofano A et al (2016) Distinctive pattern of serum elements during the progression of Alzheimer's disease. Sci Rep 6:1-12. https://doi.org/10.1038/srep22769

Pasinetti GM, Hiller-Sturmhöfel S (2008) Systems biology in the study of neurological disorders: focus on Alzheimer's disease. Alcohol Res Heal 31:60-65

Pei JJ, Tanaka T, Tung YC et al (1997) Distribution, levels, and activity of glycogen synthase Kinase-3 in the Alzheimer disease brain. J Neuropathol Exp Neurol 56:70-78. https://doi.org/10.1097/00005072-199701000-00007

Plum L, Schubert M, Brüning JC (2005) The role of insulin receptor signaling in the brain. Trends Endocrinol Metab 16:59-65. https://doi.org/10.1016/.jtem.2005.01.008

Polikov V, Block M, Zhang C, Monty Reichert W, Hong JS (2007) In Vitro models for neuroelectrodes: A paradigm for studying tissue-materials interactions in the brain. In: Indwelling Neural Implants: Strategies for Contending with the in Vivo Environment. pp. 89-115. CRC Press

Popescu C (2016) Mechanisms Implicated in Parkinson Disease from Genetic Perspective. Med Clin Rev 2. https://doi.org/10. 21767/2471-299x.1000028 
Putney JW, Tomita T (2011) Phospholipase C signaling and calcium influx. Adv Biol Regul 52:152-164. https://doi.org/10.1016/ j.advenzreg.2011.09.005.Phospholipase

Rad SK, Arya A, Karimian $\mathrm{H}$ et al (2018) Mechanism involved in insulin resistance via accumulation of $\beta$-amyloid and neurofibrillary tangles: link between type 2 diabetes and alzheimer's disease. Drug Des Devel Ther 12:3999-4021. https:// doi.org/10.2147/DDDT.S173970

Razzokov J, Yusupov M, Bogaerts A (2019) Oxidation destabilizes toxic amyloid beta peptide aggregation. Sci Rep 9:5476. https://doi.org/10.1038/s41598-019-41931-6

Reddy S, Seth R (2019) Role of Tumor Necrosis Factor in Neurodegeneration. EC Endocrinol Metab Res 4:162-171

Rehman K, Akash MSH (2016) Mechanisms of inflammatory responses and development of insulin resistance: how are they interlinked? J Biomed Sci 23. https://doi.org/10.1186/s12929-016-0303-y

Santello M, Volterra A (2012) TNFa in synaptic function: switching gears. Trends Neurosci 35:638-647. https://doi.org/10.1016/ j.tins.2012.06.001

Sasidharakurup H, Melethadathil N, Nair B, Diwakar S (2017) A Systems Model of Parkinson 's Disease 21:454-464. https://doi. org/10.1089/omi.2017.0056

Sasidharakurup H, Nair L, Bhaskar K, Diwakar S (2020) Computational Modelling of TNFa pathway in Parkinson's disease - a systemic perspective. In: Complex Networks and Their Applications VIII, In, pp 762-773

Savageau MA, Voit EO, Irvine DH (1987) Biochemical systems theory and metabolic control theory: 1. Fundamental similarities and differences. Math Biosci 86:127-145. https://doi.org/10.1016/0025-5564(87)90007-1

Schäfers M, Svensson Cl, Sommer C, Sorkin LS (2003) Tumor necrosis factor-a induces mechanical allodynia after spinal nerve ligation by activation of p38 MAPK in primary sensory neurons. J Neurosci 23:2517-2521. https://doi.org/10.1523/ jneurosci.23-07-02517.2003

Sharma N, Singh AN (2016) Exploring biomarkers for Alzheimer's disease. J Clin Diagnostic Res 10:KE01-KE06. https://doi.org/ 10.7860/JCDR/2016/18828.8166

Shetty PK, Galeffi F, Turner DA (2012) Cellular links between neuronal activity and energy homeostasis. Front Pharmacol 3:43. https://doi.org/10.3389/fphar.2012.00043

Sidoti-De Fraisse C, Rincheval V, Risler Y, et al (1998) TNF-a activates at least two apoptotic signaling cascades

Singh A, Kukreti R, Saso L, Kukreti S (2019) Oxidative stress: a key modulator in neurodegenerative diseases. Molecules 24. https://doi.org/10.3390/molecules24081583

Smith GR, Shanley DP (2013) Computational modelling of the regulation of insulin signalling by oxidative stress. BMC Syst Biol 7:1. https://doi.org/10.1186/1752-0509-7-41

Su Z, Wu Y (2020) Computational simulations of TNF receptor oligomerization on plasma membrane. Proteins Struct Funct Bioinforma 88:698-709. https://doi.org/10.1002/prot.25854

Tretter L, Dam-Vizi V (2004) Generation of reactive oxygen species in the reaction catalyzed by alpha-ketoglutarate dehydrogenase. J Neurosci 24:7771-7778. https://doi.org/10.1523/JNEUROSCI.1842-04.2004

Tucker W, Kutalik Z, Moulton V (2007) Estimating parameters for generalized mass action models using constraint propagation. Math Biosci 208:607-620. https://doi.org/10.1016/J.MBS.2006.11.009

Tweedie D, Ferguson RA, Fishman K et al (2012) Tumor necrosis factor-a synthesis inhibitor 3,6'-dithiothalidomide attenuates markers of inflammation, Alzheimer pathology and behavioral deficits in animal models of neuroinflammation and Alzheimer's disease. J Neuroinflammation 9:575. https://doi.org/10.1186/1742-2094-9-106

Tysnes OB, Storstein A (2017) Epidemiology of Parkinson's disease. J Neural Transm 124:901-905

Vidal M, Cusick ME, Barabási A-L (2011) Interactome networks and human disease. 144(6):986-998. https://doi.org/10.1016/j. cell.2011.02.016

Wang WY, Tan MS, Yu JT, Tan L (2015) Role of pro-inflammatory cytokines released from microglia in Alzheimer's disease. Ann Transl Med 3:136. https://doi.org/10.3978/j.issn.2305-5839.2015.03.49

Wang X, Huang S, Jiang Y et al (2018) Reactive astrocytes increase the expression of P-gp and Mrpl via TNF-a and NF- KB signaling. Mol Med Rep 17:1198-1204. https://doi.org/10.3892/mmr.2017.7939

Wu YY, Hsu JL, Wang HC et al (2015) Alterations of the Neuroinflammatory markers IL-6 and TRAIL in Alzheimer's disease. Dement Geriatr Cogn Dis Extra 5:424-434. https://doi.org/10.1159/000439214

Yang L, Wang H, Liu L, Xie A (2018) The role of insulin/IGF-1/PI3K/Akt/GSK3 $\beta$ signaling in parkinson's disease dementia. Front Neurosci 12. https://doi.org/10.3389/fnins.2018.00073

Yiannopoulou KG, Papageorgiou SG (2013) Current and future treatments for Alzheimer's disease. Ther Adv Neurol Disord 6: 19-33. https://doi.org/10.1177/1756285612461679

Yu Q, Du F, Douglas JT et al (2017) Mitochondrial dysfunction triggers synaptic deficits via activation of p38 MAP kinase signaling in differentiated Alzheimer's disease trans-mitochondrial Cybrid cells. J Alzheimers Dis 59:223-239. https://doi. org/10.3233/JAD-170283

Żekanowski C, Styczyńska M, Pepłońska B et al (2003) Mutations in presenilin 1, presenilin 2 and amyloid precursor protein genes in patients with early-onset Alzheimer's disease in Poland. Exp Neurol 184:991-996. https://doi.org/10.1016/S00144886(03)00384-4

Zhang G, Xia Y, Wan F et al (2018) New perspectives on roles of alpha-Synuclein in Parkinson's disease. Front Aging Neurosci 10:1-20. https://doi.org/10.3389/fnagi.2018.00370

\section{Publisher's Note}

Springer Nature remains neutral with regard to jurisdictional claims in published maps and institutional affiliations. 